\title{
Mercury $(\mathrm{Hg})$ concentration of river water and sediment in Tambang Sawah village due to gold mining without permission
}

\author{
Irwan Mulyadi*, Badrus Zaman, Sri Sumiyati \\ Master Program of Environmental Engineering, Faculty of Engineering, Diponegoro University, \\ Indonesia
}

\begin{abstract}
The rise of mining activities without permission (PETI) which was a people's mining from Dutch colonial legacy, located in the Tambang Sawah Village, Pinang Belapis District, Lebong Regency has caused environmental problems especially mercury pollution in that village river water. The sampling method refer to Japan Public Health Association (JPHA), then sample analyzed in the national standard laboratory and the results were compared with the Government Regulation of Republic Indonesia No. 82 of 2001 on Management of Water Quality and Control Over Water Pollution. Concentration of total mercury in river water at five sampling points from upstream to downstream of the Tambang Sawah Village river, respectively $<0,0003 \mathrm{ppm}, 0,0004 \mathrm{ppm}$, $0,0007 \mathrm{ppm}, 0,0008 \mathrm{ppm}$ and $0,0011 \mathrm{ppm}$ and total concentration of mercury in river sediments respectively $1.34 \mathrm{ppm}, 4.18 \mathrm{ppm}, 35.89 \mathrm{ppm}$, $50.32 \mathrm{ppm}$ and $114.37 \mathrm{ppm}$, has exceeded the threshold limit.
\end{abstract}

\section{Introduction}

Illegal gold mining activity (PETI) conducted by people of Tambang Sawah Village, Pinang Belapis Subdistrict of Lebong Regency has taken place in this area since the Dutch colonialism, continued to Japanese occupation of the Dutch, until today.

Amalgamation process is normally applied in the activity of people's gold mining (artisanal mining) in Tambang Sawah Village. Amalgamation is a process of in which rocks contain gold are mixed with mercury using tromol [1]. Waste produced from amalgamation process is collected in a temporary pond where wastewater from this pond is later released into the river as the receiving water body, while tailings or waste sediments generated from amalgamation process are collected into sacks, piled up, and stored.

Moreover, dried sediments are re-processed using cyanide $(\mathrm{NaCN})$ and dumped into a landfill which will further be carried by river flow in the form of suspension. Sediments play an important role to control the concentration of heavy metal that accumulates in the body tissue of aquatic biota [2]. In an aquatic system, sediment is an essential sinking particle besides the source of $\mathrm{Hg}$ and is also considered as the primary producer of methylmercury (MeHg) [3].

* Corresponding author:irwanmulyadi12@gmail.com 
Contamination of mercury in river sediment could occur due to natural process (weathering of mineralized rocks), traditional gold extraction (amalgamation), and industrial process that uses raw materials that contain mercury. However, investigating the source of mercury contamination requires thorough observation due to the absence of quality standard for mercury concentration in the river sediment [4].

\section{Materials and method}

This study was conducted from February to April 2020, located in river that passes through Tambang Sawah Village which also functions as the receiving water body for waste discharge of amalgamation activity. The sample analyzed consisted of sample of river water and sediment that passed through Tambang sawah Village. A total of 5 sampling points was determined, the first and second points were located in the upstream part of river at the village boundary, the third (3) point was in the center of village, while the fourth (4) and fifth (5) points were in the downstream part of river at the village boundary. Technic of sampling was done referring to Japan Public Health Association (JPHA) [5], collecting sediments that are at $10-15 \mathrm{~cm}$ from the surface using PVC pipe. Samples of sediment were separated from gravels, plant debris, and other objects. Samples were further filtered using sieve of 2 mesh, put into bottles, sealed, stored in cooler, and sent to the laboratory.

Water sampling was done using kemerer water sampler at the depth of $20 \mathrm{~cm}$ and 75 $\mathrm{cm}$, and turned into composite. Water samples were further stored into sample bottles and preserved by adding $3 \mathrm{~mL}$ of concentrated $\mathrm{HNO}_{3}$, specific for heavy metal samples.

Samples of river water and sediment were analyzed in the Laboratory of the Institution for Research and Standardization of Industry (Balai Riset dan Standarisasi Industri Padang) according to ASTM C1301-95(2001).

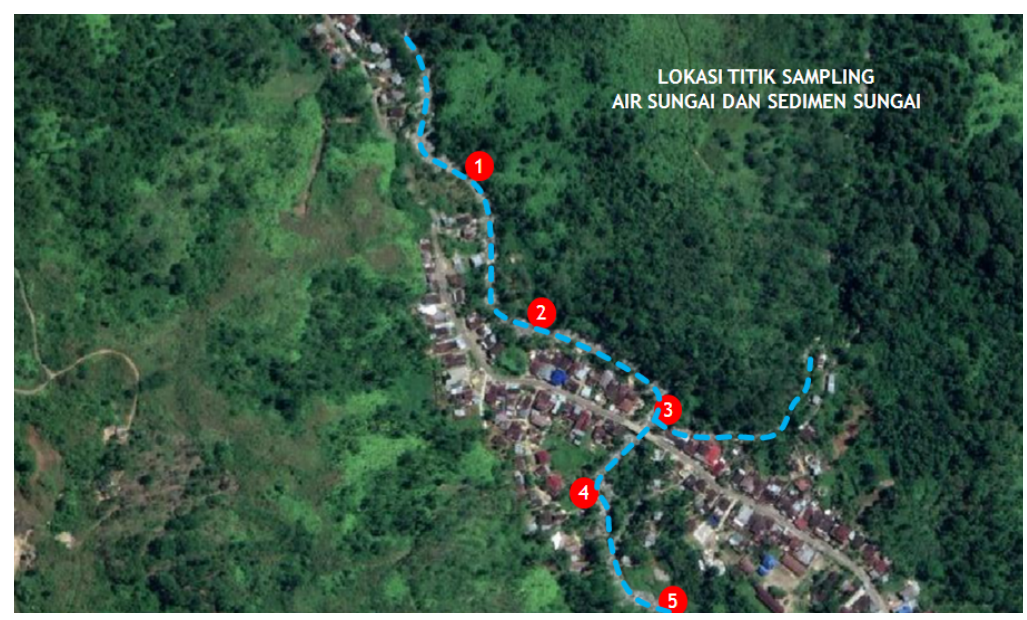

Fig. 1. Sampling location

\section{Results and discussion}

Concentration of $\mathrm{Hg}$ increases along with the increasing number of miners who release wastewater and tailings into the river. 
Table 1. Concentration of $\mathrm{Hg}$ in sample of river water

\begin{tabular}{|c|c|c|c|}
\hline No & Code of Sample & $\begin{array}{c}\text { Result of } \\
\text { Measurement }\end{array}$ & $\begin{array}{c}\text { Quality } \\
\text { Standard*) }\end{array}$ \\
\hline 1 & River Water (AP 1) & $<0,0003$ & \multirow{2}{*}{} \\
\cline { 1 - 3 } 2 & River Water (AP 2) & 0,0004 & \multirow{2}{*}{0,001} \\
\hline 3 & River Water (AP 3) & 0,0007 & \multirow{2}{*}{0,0008} \\
\cline { 1 - 3 } 4 & River Water (AP 4) & 0,0011 & \\
\hline 5 & River Water (AP 5) & 0,0011 \\
\hline
\end{tabular}

*) Government Regulation No. 82 in 2001 about the Management of Water Quality and Control over Water Pollution (Class 1)

Based on the Table 1, the highest mercury concentration in river water was observed at Point 5 with a value of $0,0011 \mathrm{ppm}$ since Point 5 was the location or the point of accumulation for river that flows through Tambang Sawah Village. Concentration of mercury at Point 1-4 ranged of $0,0003-0,0008 \mathrm{ppm}$, showing a lower value than that at Point 5 and in term of meeting the quality standards as mentioned in the Government Regulation No. 82 in 2001 about the Management of Water Quality and Control over Water Pollution (Class 1) despite the existence of PETI (illegal mining) activity within the area. It is considered that low concentration of mercury is due to the fact that mercury was not all detected in waters since this material is easily accumulated and settled.

According to the previous study, mercury is easy to dissolve and change its stability from carbonate to hydroxide that forms particle bonds in waters, then settles to form muds [6]. It is quite hard to detect mercury water surface since mercury easily binds organic maters and settles in the water bottom, thus its concentration in the sediment is possibly higher. In line with this statement, Rochyatun also found that concentration of heavy metal in the sediment is higher than that in the water as it is accumulated from sedimentation, while low concentration of heavy metal in the water is due to dilution process and effect of current pattern [7].

Table 2. Concentration of $\mathrm{Hg}$ in sample of river sediment

\begin{tabular}{|c|c|c|c|}
\hline No & Code of Sample & $\begin{array}{c}\text { Result of } \\
\text { Measurement }\end{array}$ & $\begin{array}{c}\text { Quality } \\
\text { Standard*) }\end{array}$ \\
\hline 1 & River Water (AP 1) & 1,3405 & \\
\cline { 1 - 3 } 2 & River Water (AP 2) & 4,1849 & \multirow{2}{*}{0,174} \\
\hline 3 & River Water (AP 3) & 35,8923 & \\
\hline 4 & River Water (AP 4) & 50,3214 & \\
\cline { 1 - 3 } 5 & River Water (AP 5) & 114,3742 & \\
\hline \multirow{*}{***}{ National Oceanic and Atmospheric Administration (NOAA) } \\
US Department of Commerce
\end{tabular}

Sediment with $\mathrm{Hg}$ concentration over $2 \mathrm{ppm}$ is considered as contaminated sediment [8]. As shown in this study result, the location of Point 5 obtained $\mathrm{Hg}$ contamination of 114,37 ppm (dry weight) since area surrounding Point 5 was found to accumulate mercury in the river where gold mining activity in Tambang Sawah Village took place.

High mercury concentration in the sediment of river that flows through Tambang Sawah Village is expected to have strong relationship with the existence of illegal artisanal gold miners (PETI) who applied amalgamation process which is considered to be the main reason of mercury contamination in the waters. 
Mercury carried by sediment downstream (mining area) could contaminate the river mouth since $\mathrm{Hg}$ that settles with sediments along the river forms a "hot spot" of contamination between estuary and mining area, particularly in river with slower flow or sloping topography [8].

Study of Medical Geology conducted in 2011 resulted in mercury concentration of only $0,292 \mathrm{ppm}$ in the sediment of river flows through Tambang Sawah Village [9], showing a great increase of mercury concentration in river sediment for the last 9 years.

Mercury concentration in river water should be taken into concern in future research. It is possible for mercury to continuously accumulate in the water with increasing concentration, causing environmental pollution, adverse impact on health besides its toxicity to human. The toxic forms of mercury concerning its exposure to human are methylmercury $\left(\mathrm{CH}_{3} \mathrm{Hg}^{+}\right.$and $\left.\mathrm{CH}_{3}-\mathrm{Hg}_{-}-\mathrm{CH}_{3}\right)$ and organic mercury salts, and particulate mercury chloride $(\mathrm{HgCl} 2)$. Methylmercury is formed by bacteria in the sediment and acid water. Inorganic mercury ion is acute poison. Mercury elements has a relatively shorter residence time in human body, yet residence time of methylmercury in human body is 10 times longer compared with mercury in metal form, thus causes brain malfunction, anxiety, kidney disease, and liver problem in newborns [10].

\section{Conclusion}

Concentrations of total mercury in the river water at five sampling points, from upstream to downstream part of Tambang Sawah Village river respectively were $<0,0003 \mathrm{ppm}, 0,0004$ ppm, 0,0007 ppm, 0,0008 ppm and 0,0011 ppm. Concentrations of total mercury in river sediment at five sampling points, from upstream to downstream part of Tambang Sawah Village river were 1,34 ppm, 4,18 ppm, 35,89 ppm, 50,32 ppm and 114,37 ppm, respectively.

Based on this result, concentration of mercury in river water and sediment, from upstream to downstream part of Tambang Sawah Village river continued to increase due to accumulation of people's gold mining activity that use mercury and released the toxic waste into the river.

\section{References}

1. F.H. Sualang, Kondisi, Permasalahan Pertambangan Emas trehadap Lingkungan Hidup di Propinsi Sulawesi Utara, in proceedings of "Dampak Penambangan Emas Dengan Menggunakan Merkuri Terhadap Kesehatan Manusia”, Manado, Indonesia (2001)

2. M.C. Blanchette, T. P. Haynes, Y.T.J. Kwong, M.R. Anderson, G. Veinott, J. F. Payne, C. Stirling, P. J. Sylvester, Balkema, Rotterdam, 323-331 (2001)

3. Y. Cai, R. Jaffe', R. Jones, Environ. Sci. Technol. 31, 302-305 (1997)

4. T.B. Setiabudi, Penyebaran Merkuri Akibat Usaha Pertambangan Emas di Daerah Sangon, Kabupaten Kulon Projo, D. I. Jogjakarta, Indonesia (2005)

5. Anonymous, Preventive measures against environment mercury pollution and its health effects (Japan Public Health Association, Japan, 2001)

6. Harahap, Toxicity of marine organism caused by polutan. Dalam: Marine pollution and sea life (FAO, Surrey, England, 1991)

7. Rochyatun, Diktat pengantar mata kuliah toksikologi logam berat (Fakultas Perikanan Brawijaya, Malang, Indonesia, 1997)

8. M.M. Veiga, J.A. Meech, Water Air and Soil Pollution 80, 123-132 (1995) 
9. Arief R., Sukandar M., Putra C., Budhiastuti S.E., Misdawarni, Suratno, Penelitian Geologi Medis Daerah Lebong Tambang Kabupaten Lebong, Provinsi Bengkulu, in proceedings of Pusat Sumber Daya Geologi (2011)

10. Yulianti R., Sukiyah E., Sulaksanak N., Dampak Limbah Penambangan Emas Tanpa Izin (PETI) Terhadap Kualitas Air Sungai Limun Kabupaten Sarolangun Propinsi Jambi (Scientific Contribution UNPAD, Bandung, Indonesia, 2016) 